Cite this: RSC Adv., 2014, 4, 10157

\title{
Establishment of two complementary in vitro assays for radiocopper complexes achieving reliable and comparable evaluation of in vivo stability $\dagger$
}

\begin{abstract}
K. Zarschler, + M. Kubeilł and H. Stephan*
The development of novel radiopharmaceuticals for imaging and therapy requires rapid and reproducible in vitro assays to estimate their in vivo stability and dissociation behaviour. In general, these assays should allow an assessment of dissociation of the radiometal from the radiopharmaceuticals. In the past, a series of chemical challenges has been widely used to estimate complex stability under non-physiological and non-radiotracer conditions providing limited information on the potential in vivo stability. In contrast, we herein present two independent in vitro methods to measure the stability of radiocopper complexes under physiologically relevant conditions. To quantify and compare the dissociation behaviour of six wellestablished ${ }^{64} \mathrm{Cu}$ chelates (TETA, DOTA, NOTA, Cyclam, diamSar and EDTA), we combine a protein challenge experiment considering the stability of the chelates in the presence of human superoxide dismutase with a serum assay measuring the stability of the radiometal complexes against human serum. Unlike HPLC- and TLC-based analytical techniques, we describe the stability assessments by standard gel electrophoretic procedures, which allow a timesaving workflow as well as simultaneous processing and comparative analysis of a variety of copper-containing chelates and conjugates thereof. $\left[{ }^{64} \mathrm{Cu}\right] \mathrm{Cu}$-diamSar is the most kinetically stable ligand, whereas the acyclic chelate $\left[{ }^{64} \mathrm{Cu}\right] \mathrm{Cu}$-EDTA underwent an almost complete complex dissociation. Furthermore, kinetic stability studies in human serum carried out for $\left[{ }^{64} \mathrm{Cu}\right] \mathrm{Cu}$-diamSar revealed no substantial time-dependent influence under commonly used labelling conditions. Both described assays, the protein challenge experiment as well as the serum stability assay, are not restricted to radiocopper, but may be adopted for other radiometal containing chelates.
\end{abstract}

Received 4th December 2013 Accepted 30th January 2014

DOI: $10.1039 / c 3 r a 47302 c$

www.rsc.org/advances diseased and healthy tissue and exposure of healthy tissue to potentially damaging radiation. In the last decades new bifunctional copper-containing chelating agents (BFCAs), showing remarkable thermodynamic stabilities, have been developed to overcome these limitations. Valuable information about relative in vivo kinetic stability can be indirectly gained from metal ion exchange $\mathrm{e}^{\mathbf{1 6 , 1 7}}$ and cross ligand challenge experiments. ${ }^{16,18-26}$ Acid-assisted dissociation studies have been also applied. ${ }^{27,28}$ These methods are supposed to reflect the stability of BFCAs for copper(II), while not really associated with in vivo conditions. In this context, serum stability experiments are more suitable. ${ }^{29-33}$ Hence, the understanding of copper metabolism, particularly proteins which are involved, is crucial to achieve reliable predictions of prospective in vivo stability using in vitro assays.

In biological systems, copper homeostasis is tightly regulated and copper itself functions as a structural and catalytic cofactor for proteins in a multitude of processes such as oxygen transport, energy generation, iron acquisition, blood clotting, oxidative stress protection and normal cell growth. ${ }^{34-39}$ Copper ions exist in living organisms in two oxidation states, oxidized
Institute of Radiopharmaceutical Cancer Research, Helmholtz-Zentrum Dresden-Rossendorf, Bautzner Landstraße 400, D-01328 Dresden, Germany. E-mail: h.stephan@hzdr.de

$\dagger$ Electronic supplementary information (ESI) available. See DOI: 10.1039/c3ra47302c

\$ These authors contributed equally. 
copper(II) and reduced copper(I), and this redox activity is utilized by a wide variety of enzymes. However, the same redox properties cause cellular oxidative damage when the transition metal occurs in excessive concentrations. Defence mechanisms are designed to chelate immediately copper ions to proteins, protecting the cells against redox-induced damages. ${ }^{\mathbf{4 0 , 4 1}}$ Once ionic copper enters the blood, it is immediately taken up by serum proteins (albumin, $\alpha_{2}$-macroglobulin) that deliver copper efficiently to the liver, a central organ of copper homeostasis and the kidney. ${ }^{\mathbf{4 2 , 4 3}}$ Serum albumin represents one of the most abundant proteins of the vascular system and possesses highspecific binding sites for copper(II). ${ }^{\mathbf{4 2 , 4 4 - 4 7}}$ Albumin- and $\alpha_{2^{-}}$ macroglobulin-bound copper is rapidly exchanged between both serum proteins and is released therefrom directly to specific transporter systems in the cell membrane. Before import of copper into the cytosol mediated by Ctr1 (copper transporter 1), an integral membrane protein highly-specific for copper(I), albumin- and $\alpha_{2}$-macroglobulin-bound copper(II) is reduced to copper(I) by a putative cell surface metalloreductase. ${ }^{48}$ Once in the cytosol of a mammalian cell, copper is routed by small proteins known as metallochaperones to $\mathrm{Cu}$ dependent enzymes (superoxide dismutase, cytochrome $c$ oxidase) or incorporated into $\mathrm{Cu}$-dependent proteins traversing the secretion pathways such as caeruloplasmin. ${ }^{49-53}$ Copper/zinc superoxide dismutase SOD1 is a homodimeric enzyme (32 kDa), which is mostly abundant in the cells of liver and kidney as well as erythrocytes. Its major function is the catalytic conversion of superoxide radicals to hydrogen peroxide and oxygen protecting the cell against oxidative damage. This disproportionation is dependent on an active site embedding the metal ions $\mathrm{Cu}$ and Zn. ${ }^{54,55}$ Several stability studies of ${ }^{64} \mathrm{Cu}$-labelled BFCA biomolecule conjugates have significantly pointed to the dissociation of ${ }^{64} \mathrm{Cu}$ in the presence of SOD. ${ }^{31,32}$

Herein we describe two independent in vitro methods for radiocopper complexes representing a complementary combination of a protein challenge experiment and a serum stability assay. The former approach considers the stability of radiopharmaceuticals in the presence of human $\mathrm{Cu} / \mathrm{Zn}-\mathrm{SOD}$, whereas the latter assay measures the stability of the radiometal complex against human serum. We compared six well-established ${ }^{64} \mathrm{Cu}$ labelled BFCAs (Fig. 1) in order to estimate their radiocopper dissociation in vivo: TETA 1 (1,4,8,11-tetra(carboxymethyl)1,4,8,11-tetraazacyclotetradecane), DOTA 2 (1,4,7,10-tetra(carboxymethyl)-1,4,7,10-tetraazacyclododecane), NOTA 3 (1,4,7-tri(carboxymethyl)-1,4,7-triazacyclononane), Cyclam 4 (1,4,8,11-tetraazacyclotetradecane), diamSar 5 (1,8-diamino-3,6,10,13,16,19-hexaazabicyclo[6.6.6]icosane) and EDTA 6 (2-[2-[bis(carboxymethyl)amino]ethyl-(carboxymethyl)amino]acetic acid).

Since the exchange of ${ }^{64} \mathrm{Cu}$ to the respective proteins was quantified using gel electrophoresis techniques, the presented assays allow simultaneous analysis of multiple samples in less than four hours. Furthermore, these techniques also allow a stability assessment of ${ }^{64} \mathrm{Cu}$-labelled BFCA-protein conjugates. For this approach, we coupled the single-domain antibody (sdAb) 7C12 with 2-(p-isothiocyanatobenzyl)-NOTA (SCN-Bn-NOTA) to produce a NOTA-Bn-sdAb conjugate. This particular sdAb represents a promising vector molecule for molecular imaging applications, since it possesses high affinity for<smiles>O=C(O)CN1CCCN(CC(=O)O)CCCN(CC(=O)O)CCC1</smiles>

TETA

1

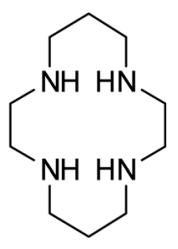

Cyclam<smiles>O=C(O)CN1CCN(CC(=O)O)CCN(CC(=O)O)CCN(CC(=O)O)CC1</smiles>

DOTA

2

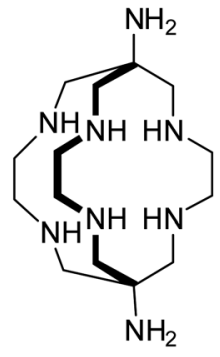

diamSar<smiles>O=C(O)CN1CCN(CC(=O)O)CCN(CC(=O)O)CC1</smiles>

NOTA

3<smiles>O=C(O)CN(CCN(CC(=O)O)CC(=O)O)CC(=O)O</smiles>

EDTA

Fig. 1 Structures of the ligands used in this study. The well-established azamacrocycles for radiocopper complexation TETA 1, DOTA 2, NOTA 3, Cyclam 4, diamSar 5 as well as the acyclic chelator EDTA 6 were investigated by a superoxide dismutase challenge experiment and a serum stability assay. 
the epidermal growth factor receptor (EGFR) ${ }^{56}$ which is overexpressed and/or deregulated in a wide range of tumour entities. ${ }^{57}$

\section{Results and discussion}

To study the kinetic stability of ${ }^{64} \mathrm{Cu}$ labelled complexes, we established two independent in vitro methods representing a complementary combination of a superoxide dismutase (SOD) challenge experiment and a serum stability assay. It has been reported that the kinetic, rather than the thermodynamic stability plays an important role in the evaluation of ${ }^{64} \mathrm{Cu}$ chelates for in vivo applications. Therefore, a couple of wellestablished radiocopper azamacrocycles 1-5 and EDTA 6 were investigated to quantify the complex dissociation and transchelation of ${ }^{64} \mathrm{Cu}$ to serum proteins and SOD. These macrocyclic chelates possess different in vivo behaviours which result from a kinetic stability dependent resistance against transchelation. ${ }^{4,9,27,28,58-60}$ In order to estimate the stability of the radiometal complexes, they were incubated in the presence of human serum and human SOD and the level of complex dissociation was analysed by polyacrylamide gel electrophoresis (PAGE) followed by electronic autoradiography. To quantify the data, we used free $\left[{ }^{64} \mathrm{Cu}\right] \mathrm{CuCl}_{2}$ as $100 \%$ normalized standard which was treated in the same way as the chelators. The linear dependence of radioluminographic blackening intensities and $\left[{ }^{64} \mathrm{Cu}\right] \mathrm{CuCl}_{2}$ activities is shown in Fig. S1.† The described workflow based on standard gel electrophoretic procedures allows simultaneous processing and comparative analysis of a multitude of copper-containing chelates and conjugates thereof in less then $4 \mathrm{~h}$. In contrast, radio-HPLC (SEC) analysis of a comparable number of samples would take more time, whereas simultaneous analysis is impossible. Alternatively, radio-TLC procedure is a rapid method to analyse the stability, but $\left[{ }^{64} \mathrm{Cu}\right]$ Cu-labelled conjugates possessing antibodies or peptides as targeting units show often the same retention behaviour as $\left[{ }^{64} \mathrm{Cu}\right] \mathrm{Cu}$-labelled serum proteins. Quantification and identification is in these cases not possible. In fact, the PAGE allows the same procedures for almost all potential radiopharmaceuticals to be studied without developing time-consuming tailor-made retention conditions for each sample.

\section{SOD challenge experiment}

Fig. 2 represents an exemplary depiction of a native polyacrylamide gel obtained by the described SOD challenge. In the Coomassie stained gel, two distinct bands with different isoelectric points are detectable, which may represent distinct SOD isoforms or SOD with varying degrees of post-translational processing. ${ }^{\mathbf{6 1 6 2}}$ The autoradiographic scan shows in each lane corresponding radioactive protein bands. The enzyme was incubated before with radiolabelled samples 1-6 and the reference $\left[{ }^{64} \mathrm{Cu}\right] \mathrm{CuCl}_{2}$ as described in the methods section.

The different blackening intensities of the bands originate from different amounts of ${ }^{64} \mathrm{Cu}$, which was demetalated and incorporated into SOD. Non-specific binding of the radiolabelled chelates with the enzyme as a reason for the strong signal (rather then transchelation) can be excluded, since such (a)

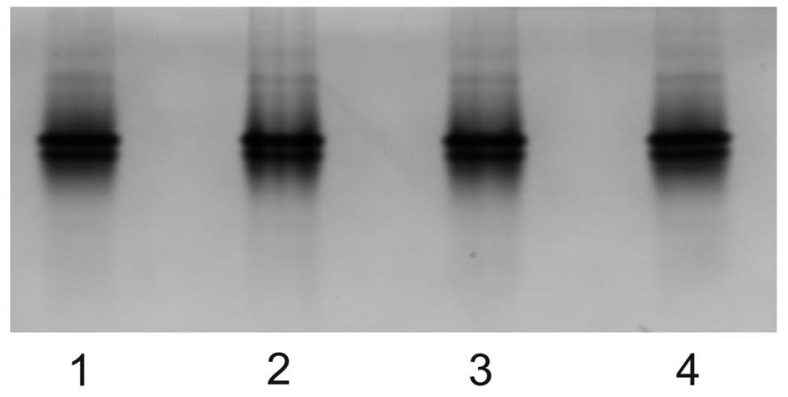

(b)

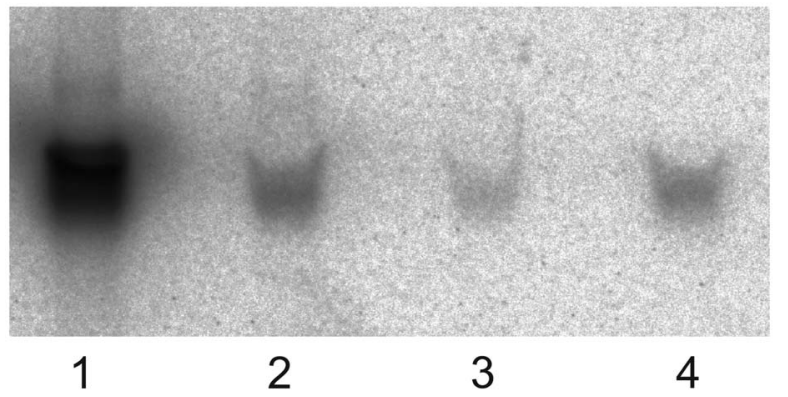

Fig. 2 Analysis of ${ }^{64} \mathrm{Cu}$ incorporation into human erythrocyte superoxide dismutase (SOD). Colloidal Coomassie stained native polyacrylamide gel (a) and autoradiography (b) showing ${ }^{64} \mathrm{Cu}$-labelled bands of SOD: lane $1\left[{ }^{64} \mathrm{Cu}\right] \mathrm{CuCl}_{2}$; lane $2\left[{ }^{64} \mathrm{Cu}\right] \mathrm{Cu}$-DOTA; lane 3 $\left[{ }^{64} \mathrm{Cu}\right] \mathrm{Cu}-\mathrm{NOTA}$; lane $4\left[{ }^{64} \mathrm{Cu}\right] \mathrm{Cu}$-Cyclam.

interactions would influence the electrophoretic mobility of the proteins. However, the migration of SOD, which is during native PAGE mainly depending on the molecular mass and intrinsic charge, is identical between the reference and the different chelates. Conversely, non-specific interactions between the radiolabelled chelates and the enzyme would result in shifted bands, what is obviously not the case.

Quantitative determination of transchelation is related to the reference $\left[{ }^{64} \mathrm{Cu}\right] \mathrm{CuCl}_{2}$ and can be calculated using the following equations:

$$
\begin{gathered}
X_{\text {reference }}=\text { integral/activity } \\
Y_{\text {sample }}=\text { integral/activity }
\end{gathered}
$$

transchelation $\left[\%\right.$ of control] $=\left(Y_{\text {sample }} / X_{\text {reference }}\right) \times 100$

Using the AIDA software, the different blackening intensities were integrated and the resulting values were divided by the corresponding activities of the respective ${ }^{64} \mathrm{Cu}$ complexes $\left(Y_{\text {sample }}\right)$ or the $\left[{ }^{64} \mathrm{Cu}\right] \mathrm{CuCl}_{2}$ reference $\left(X_{\text {reference }}\right)$. The transchelation rate is defined as the ratio of $Y_{\text {sample }}$ and $X_{\text {reference }}$.

Fig. 3 summarizes the quantitative results of incorporated ${ }^{64} \mathrm{Cu}$ into SOD according to the investigated radiolabelled chelates 1-6. All macrocyclic ligands showed a high resistance against transchelation in the presence of human SOD. Respectively, the diamSar $5\left(0.6 \pm 0.1 \%\right.$ transchelation of ${ }^{64} \mathrm{Cu}$ to SOD) 


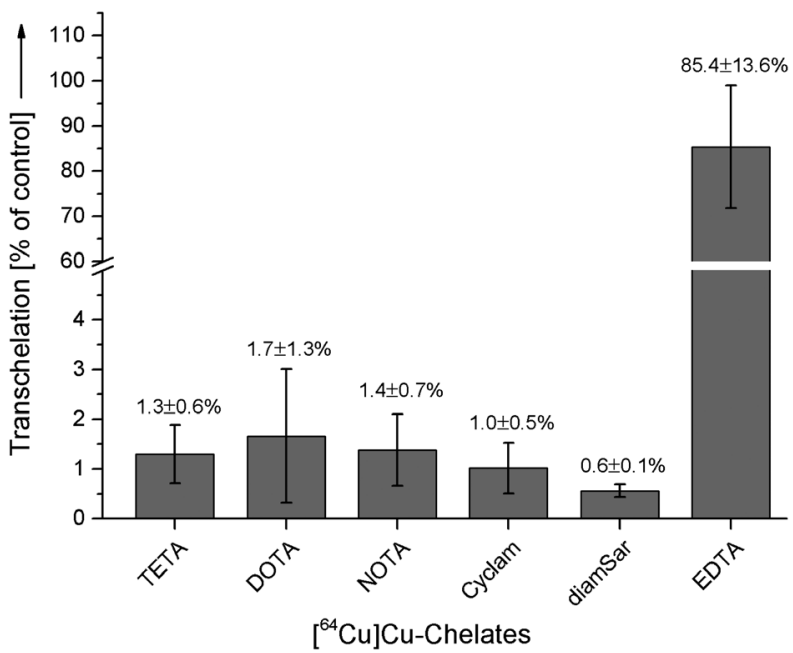

Fig. $3{ }^{64} \mathrm{Cu}$-transchelation [\% of control] to human erythrocyte superoxide dismutase (SOD) for ${ }^{64} \mathrm{Cu}$-labelled ligands 1-6. After radiolabelling, indicated $\left[{ }^{64} \mathrm{Cu}\right] \mathrm{Cu}$-chelates were incubated for $1 \mathrm{~h}$ at $37^{\circ} \mathrm{C}$ with excess SOD and subsequently separated by native PAGE. Following electronic autoradiography, gels were stained with colloidal Coomassie staining solution. Quantitative analysis of average band intensities was performed as described in the results section. Each point represents the mean \pm SD of three samples.

ligand possesses the highest stability after $1 \mathrm{~h}$ incubation in the SOD challenge experiment. While the acyclic radiolabelled ligand EDTA 6 underwent a nearly complete transchelation $(85.4 \pm 13.6 \%)$ in the presence of SOD under the same conditions.

\section{Serum stability assay}

In Fig. 4 an exemplary depiction of a non-reducing SDS polyacrylamide gel obtained by the described serum stability assay is shown.

A prominent protein band in the size range of approximately $65 \mathrm{kDa}$ is visible in the autoradiographic scan, which corresponds most likely to radioactive serum albumin. Other serum proteins with high-affinity sites for copper(II) such as $\alpha_{2}$-macroglobulin $(\sim 180 \mathrm{kDa})$ are not visible due to the predominantly low abundance in human serum and the rather low in vivo application-related activity of $\left[{ }^{64} \mathrm{Cu}\right] \mathrm{CuCl}_{2}$. However, if substantially higher activities were used for radiolabelling the ${ }^{64} \mathrm{Cu}$ chelates, an additional faint protein band is visible in the autoradiographic scan in the size $>100 \mathrm{kDa}$ (data not shown). Although not investigated in more detail here, this band may correspond to serum caeruloplasmin, which represents a $132 \mathrm{kDa} \alpha_{2}$-glycoprotein with the potential to bind six copper ions. ${ }^{\mathbf{4 3}, 63}$

As explained for the SOD challenge, the different blackening intensities of the albumin bands originate from different amounts of radiocopper, which dissociates from the chelate upon incubation with serum and which is subsequently bound primarily by albumin. Since no shift in the radioactive albumin band is detectable between the different samples and the reference, non-specific interactions of the radiolabelled chelates with the protein are unlikely, but cannot be excluded completely. (a)

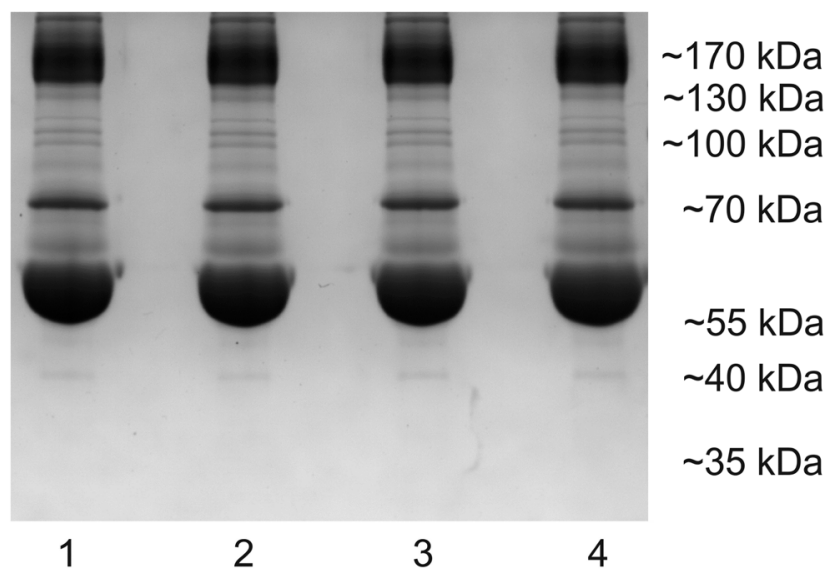

(b)

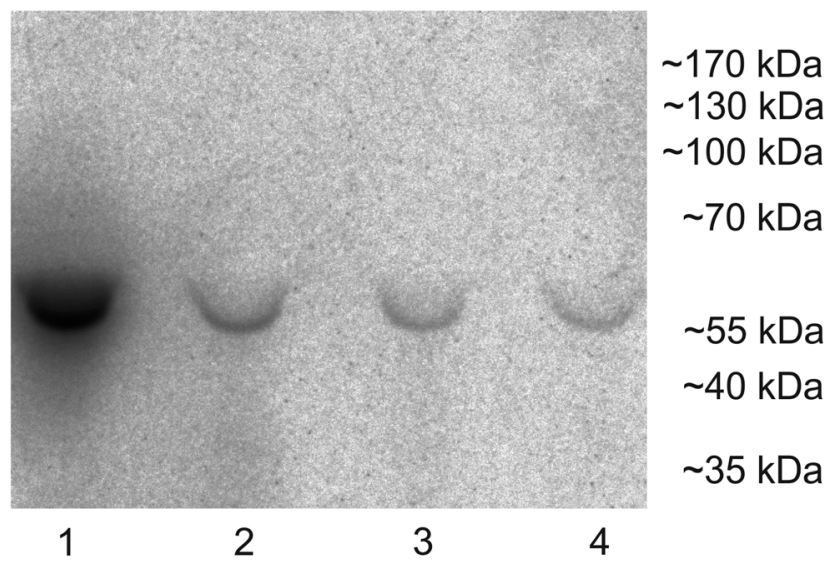

Fig. 4 Analysis of ${ }^{64} \mathrm{Cu}$-incorporation into human serum proteins. Colloidal Coomassie stained SDS-polyacrylamide gel (a) and autoradiography (b) showing ${ }^{64} \mathrm{Cu}$-labelled bands of human serum proteins: lane $1\left[{ }^{64} \mathrm{Cu}\right] \mathrm{CuCl}_{2}$; lane $2\left[{ }^{64} \mathrm{Cu}\right] \mathrm{Cu}$-DOTA; lane $3\left[{ }^{64} \mathrm{Cu}\right] \mathrm{Cu}-\mathrm{NOTA}$; lane $4\left[{ }^{64} \mathrm{Cu}\right] \mathrm{Cu}$-Cyclam.

Upon incubation of NOTA-Bn-sdAb with human serum, additional bands with the size of approximately $14 \mathrm{kDa}$ and $>70 \mathrm{kDa}$ are visible in the autoradiographic scan (Fig. 5). The former represents the radiolabelled protein-NOTA conjugate, whereas the bands with molecular weights of more than $70 \mathrm{kDa}$ could correspond to complexes of radiolabelled NOTA-Bn-sdAb and serum circulating soluble isoforms of EGFR (sEGFR). Several of these soluble receptor isoforms have been detected in the sera of normal humans and cancer patients. Alternative splicing events of EGFR mRNAs and proteolytic cleavage of fulllength transmembrane EGFR isoforms are the reasons for the localisation of these sEGFR proteins in human serum. ${ }^{64}$ Since the herein used sdAbs possess high affinity for the extracellular domain of EGFR presented by human cancer cells, they almost certainly bind soluble receptor isoforms as well.

The quantitative determination of complex stability in human serum for ${ }^{64} \mathrm{Cu}$-labelled chelates was calculated with the same method as for the SOD challenge (Fig. 6). 
(a)

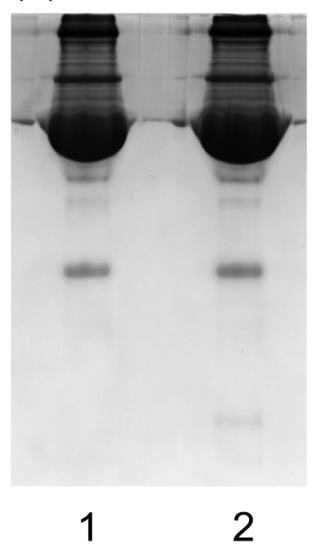

(b)

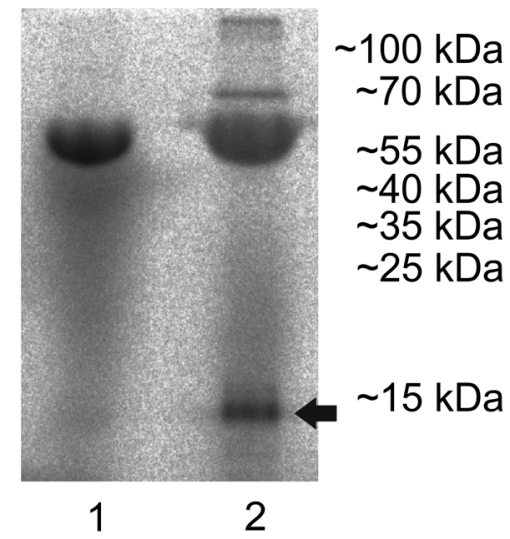

Fig. 5 Serum stability of NOTA-Bn-protein conjugate. Colloidal Coomassie stained SDS-polyacrylamide gel (a) and autoradiography (b) showing ${ }^{64} \mathrm{Cu}$-labelled bands of human serum proteins and single domain antibody (sdAb): lane $1\left[{ }^{64} \mathrm{Cu}\right] \mathrm{CuCl}_{2}$; lane $2\left[{ }^{64} \mathrm{Cu}\right] \mathrm{Cu}-\mathrm{NOTA}$ $\mathrm{Bn}-\mathrm{sdAb}$. The band corresponding to NOTA-Bn-sdAb is highlighted by an arrow.

It is worth noting that the serum stability assay supports the trends of stability obtained by the SOD challenge. The sarcophagine ligand diamSar 5 showed only marginal ${ }^{64} \mathrm{Cu}$ transchelation to albumin $(1.7 \pm 0.5 \%)$ after $1 \mathrm{~h}$ of incubation. As expected, radiocopper dissociates completely from ${ }^{64} \mathrm{Cu}$ labelled EDTA $6(100 \pm 12 \%)$ and is subsequently incorporated by albumin illustrating impressively the decreased stability associated with the acyclic structure. In contrast, the widely used ${ }^{64} \mathrm{Cu}$-labelled azamacrocycles $\left[{ }^{64} \mathrm{Cu}\right] \mathrm{Cu}$-TETA $(4.2 \pm 2.3 \%)$,

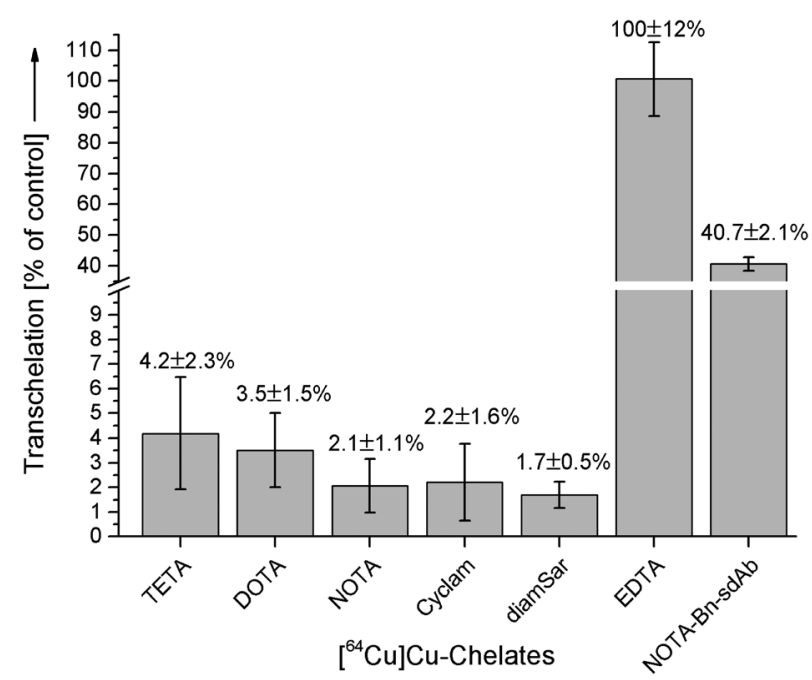

Fig. $6{ }^{64} \mathrm{Cu}$-transchelation [\% of control] in human serum for ${ }^{64} \mathrm{Cu}$ labelled ligands 1-6 and protein conjugate. After radiolabelling, indicated ${ }^{64} \mathrm{Cu}$-species were incubated for $1 \mathrm{~h}$ at $37^{\circ} \mathrm{C}$ in human serum and subsequently separated by SDS-PAGE. Following electronic autoradiography, gels were stained with colloidal Coomassie staining solution. Quantitative analysis of average band intensities was performed as described in the results section. Each point represents the mean \pm SD of three samples.

$\left[{ }^{64} \mathrm{Cu}\right] \mathrm{Cu}$-DOTA $(3.5 \pm 1.5 \%)$ and $\left[{ }^{64} \mathrm{Cu}\right] \mathrm{Cu}$-NOTA $(2.1 \pm 1.1 \%)$ remain relatively intact upon incubation in human serum for $1 \mathrm{~h}$ suggesting a high resistance towards albumin. However, conjugation of NOTA to the sdAb resulted in a substantial decrease in kinetic stability (40.7 $\pm 2.1 \%)$. This finding emphasizes that the adjacencies may significantly influence the stability of the formed copper complex. For example, exposed amino acid residues of the sdAb itself can compete with the chelator, especially if the central ion is not completely shielded. However, the developed assays offer the possibility to rapidly figure out the most appropriated chelator system to be introduced in any system of choice.

Both methods, the SOD challenge as well as the serum stability assay, identified the macrocyclic ligand diamSar the most stable out of the six examined ${ }^{64} \mathrm{Cu}$ chelates. This result confirms recent in vitro and in vivo data. ${ }^{60}$ The radiocopper azamacrocyclic acid derivatives 1-3 show very similar kinetic stability, whereas cyclam $\mathbf{4}$ appears to be slightly less prone to dissociation. Among these BFCAs, cyclam forms the most stable copper(II) complex. ${ }^{65,66}$ In vivo dissociation of ${ }^{64} \mathrm{Cu}$ from macrocyclic chelates such as TETA and binding to rat liver located SOD has been described previously. ${ }^{31,67}$ Therein, the major metabolite in liver homogenates from rats sampled $20 \mathrm{~h}$ post-injection was identified to be SOD. Boswell and colleagues performed comparative in vivo stability analysis of a series of ${ }^{64} \mathrm{Cu}$-labelled macrocyclic complexes including TETA and DOTA. ${ }^{32}$ In rat liver extracts, the majority of protein-bound ${ }^{64} \mathrm{Cu}$ was associated with SOD, whereas in blood extracts mainly ${ }^{64} \mathrm{Cu}$-labelled rat albumin was detected. Since this particular study, the amount of protein bound ${ }^{64} \mathrm{Cu}$ was calculated from integration of size-exclusion chromatograms, the values cannot be compared. However, unlike with published data concerning

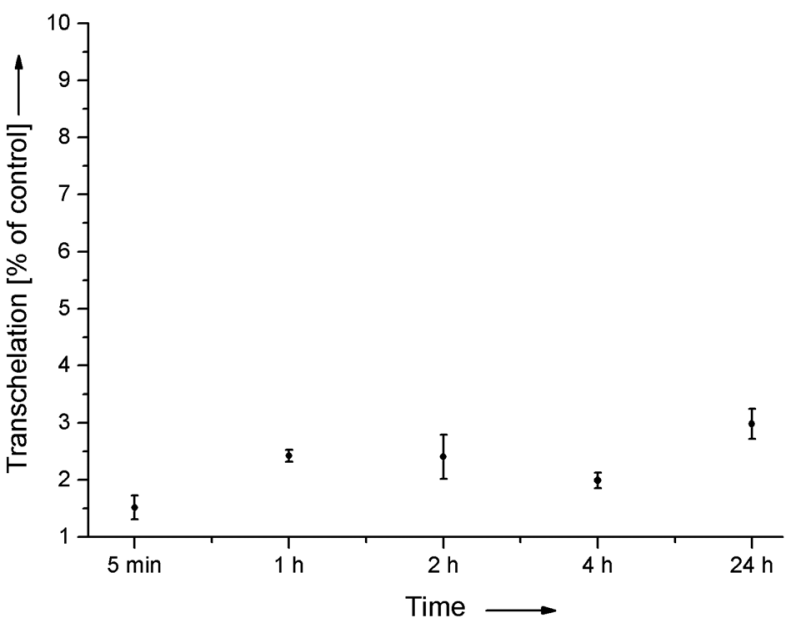

Fig. $7{ }^{64} \mathrm{Cu}$-transchelation [\% of control] in human serum for $\left[{ }^{64} \mathrm{Cu}\right]-$ $\mathrm{Cu}$-diamSar as function of time. After radiolabelling of diamSar (10 $\mathrm{nmol}$ ), the corresponding ${ }^{64} \mathrm{Cu}$-complexes were incubated for different time periods ranging from $5 \mathrm{~min}$ to $24 \mathrm{~h}$ at $37^{\circ} \mathrm{C}$ in human serum and subsequently separated by SDS-PAGE. Following electronic autoradiography, gels were stained with colloidal Coomassie staining solution. Quantitative analysis of average band intensities was performed as described in the results section. Each point represents the mean \pm SD of three samples. 
the high instability of ${ }^{64} \mathrm{Cu}$-DOTA in rat liver extracts, our results showed no substantial release of ${ }^{64} \mathrm{Cu}$ to SOD $(1.7 \pm 1.3 \%)$.

Time-dependent studies were performed choosing $\left[{ }^{64} \mathrm{Cu}\right] \mathrm{Cu}-$ diamSar to measure the kinetic stability in human serum. Data of kinetic stability as a function of time were obtained after certain incubation periods ( $5 \mathrm{~min}, 1 \mathrm{~h}, 2 \mathrm{~h}, 4 \mathrm{~h}$ and $24 \mathrm{~h}$ ) and were analysed in the same manner as described above, except that the initial activity was increased to $\sim 40 \mathrm{MBq}\left[{ }^{64} \mathrm{Cu}\right] \mathrm{CuCl}_{2}$. The results are depicted in Fig. 7 and clearly show no significant increase of transchelation after one hour. In other words, also long term exposure of $\left[{ }^{64} \mathrm{Cu}\right] \mathrm{Cu}$-diamSar to human serum at physiological temperature induces no transchelation of radiocopper to serum proteins.

\section{Experimental}

\section{General materials}

A Direct-Q 3 UV water purification system from Millipore (Merck $\mathrm{KGaA}$ ) was applied for producing deionized water. The resistance of deionized water was 18.2 M . DOTA (Cat. \#C 032) and NOTA (Cat. \#C 082) were purchased from CheMatech. DiamSar was synthesized according the literature. ${ }^{68}$ SCN-Bn-NOTA (Cat. \#B-605) was purchased from Macrocyclics. Cyclam (Cat. \#259160), TETA (Cat. \#400408), superoxide dismutase from human erythrocytes (Cat. \#S9636) as well as 2-[4-(2-hydroxyethyl)piperazin-1-yl]ethanesulfonic acid (HEPES; Cat. \#H3375) were purchased from Sigma-Aldrich. Human serum "Off the clot" (Cat. \#S 01049.1) was obtained from Biochrom AG and 2( $N$-morpholino)ethanesulfonic acid (MES; Cat. \#A1074) was delivered by Applichem. The radiolabelling process of the chelators was monitored by radio-TLC and evaluated using a radioactivity thin layer analyser (Rita Star, Raytest). Radioactivity was counted with ISOMED 2010 (MED Nuklear-Medizintechnik Dresden $\mathrm{GmbH}$ ). The polyacrylamide gels were exposed to reusable imaging plates for $10 \mathrm{~min}$ and subsequently read by a radioluminography laser scanner BAS-1800II (Raytest). The difference in the relative proportions of ${ }^{64} \mathrm{Cu}$ complex and free ${ }^{64} \mathrm{Cu}$ provides a measure of the kinetic stability of the ${ }^{64} \mathrm{Cu}$ complex. The resulting images were normalized to $100 \%$ free ${ }^{64} \mathrm{Cu}$ as reference. Each sample was investigated a minimum of three times in independent experiments and results are reported as the mean with standard deviations (SD).

\section{Radiochemistry}

The production of ${ }^{64} \mathrm{Cu}$ was performed at Cyclone® $18 / 9$ (Helmholtz-Zentrum Dresden-Rossendorf) in a ${ }^{64} \mathrm{Ni}(\mathrm{p}, \mathrm{n}){ }^{64} \mathrm{Cu}$ nuclear reaction with specific activities of 150-250 GBq $\mu \mathrm{mol}^{-1}$ $\mathrm{Cu}$ diluted in $\mathrm{HCl}(10 \mathrm{mM}){ }^{69}$ The general procedures for radiolabelling were as follow: To each ligand $(10 \mathrm{nmol}$, stock solution of $1 \mathrm{mg} \mathrm{mL}{ }^{-1}$ diluted in $\mathrm{H}_{2} \mathrm{O}$ ) was added $\left[{ }^{64} \mathrm{Cu}\right] \mathrm{CuCl}_{2}$ (10-14 MBq in $100 \mu \mathrm{L}$ of $100 \mathrm{mM} \mathrm{MES} / \mathrm{NaOH}$ buffer pH 5.5) followed by $1 \mathrm{~h}$ incubation at $25{ }^{\circ} \mathrm{C}$. Formation of the complexes were analysed by radio-TLC using different stationary and mobile phases (see Table $\mathrm{S} 1 \dagger$ ). The radiochemical purity were higher than 99\%, otherwise they were rejected. Importantly, the
$\mathrm{pH}$ was adjusted to $\mathrm{pH} 7.6$ using $1 \mathrm{M}$ HEPES/NaOH buffer pH $8.0(50 \mu \mathrm{L})$ after radiolabelling.

\section{Preparation of radiolabelled protein-NOTA conjugate}

Single-domain antibodies (sdAbs) were expressed and purified as described recently. ${ }^{70}$ For conjugation reaction, a mixture of SCN-Bn-NOTA (60 $\mu \mathrm{mol}, 33.6 \mathrm{mg})$ and sdAbs (0.6 $\mu \mathrm{mol}, 9.0 \mathrm{mg})$ in bicarbonate buffer ( $50 \mathrm{mM} \mathrm{NaHCO} 3,150 \mathrm{mM} \mathrm{NaCl}, \mathrm{pH} 8.5$ ) was allowed to react for $20 \mathrm{~h}$ at room temperature in the dark. The reaction mixture was purified by dialysis (100 mM MES/ $\mathrm{NaOH}, 150 \mathrm{mM} \mathrm{NaCl}, \mathrm{pH}$ 5.5) using Spectra/Por Float-A-Lyzer G2 with a molecular weight cut off of 3.5-5 kDa from Spectrum Laboratories (Cat. \#G235053) to remove non-conjugated small molecules. To NOTA-conjugated sdAbs (10 pmol, $150 \mu \mathrm{g}),\left[{ }^{64} \mathrm{Cu}\right]-$ $\mathrm{CuCl}_{2}(10-14 \mathrm{MBq}$ in $100 \mu \mathrm{L}$ of $100 \mathrm{mM} \mathrm{MES} / \mathrm{NaOH}$ buffer $\mathrm{pH}$ 5.5) was added followed by $1 \mathrm{~h}$ incubation at $25^{\circ} \mathrm{C}$. An aliquot of the solution $(5 \mu \mathrm{L})$ was combined with EDTA ( 2 nmol, pH 7.0) and the labelling process of the NOTA-conjugated $\operatorname{sdAbs}\left(R_{\mathrm{f}}=\right.$ 0.2 ) was monitored by radio-TLC using ITLC-SA plates in combination with a mobile phase of $\mathrm{NaCl}(0.9 \%)$ in $\mathrm{H}_{2} \mathrm{O}$. As reference, separate radio-TLC analysis of $\left[{ }^{64} \mathrm{Cu}\right] \mathrm{Cu}-\mathrm{EDTA}\left(R_{\mathrm{f}}=1\right)$ was performed in the same mobile phase. Importantly, the $\mathrm{pH}$ was adjusted to $\mathrm{pH} 7.6$ using $1 \mathrm{M}$ HEPES/NaOH buffer $\mathrm{pH} 8.0$ (50 $\mu \mathrm{L})$ after radiolabelling.

\section{Superoxide dismutase assay}

Human erythrocyte superoxide dismutase (SOD) was reconstituted in $\mathrm{H}_{2} \mathrm{O}$ to a protein concentration of $1 \mu \mathrm{g} \mu \mathrm{L}^{-1}(\sim 4$ units per $\mu \mathrm{L})$ and stored in aliquots $(10 \mu \mathrm{L}, 0.3 \mathrm{nmol})$ at $-20{ }^{\circ} \mathrm{C}$. For SOD experiments, aliquots were thawed on ice and $\left[{ }^{64} \mathrm{Cu}\right] \mathrm{Cu}$ labelled ligands 1-6 $(0.1 \mathrm{nmol}, 1.5 \mu \mathrm{L})$ or $\left[{ }^{64} \mathrm{Cu}\right] \mathrm{CuCl}_{2}$ as reference were added to SOD $(0.3 \mathrm{nmol}, 10 \mu \mathrm{g})$. The mixtures were incubated for $1 \mathrm{~h}$ at $37{ }^{\circ} \mathrm{C}$ followed by adding 1 volume native sample buffer (Bio-Rad Laboratories, Cat. \#161-0738). The samples were separated using non-reducing and non-denaturing polyacrylamide gel electrophoresis (PAGE) with acrylamide concentrations of $15 \%$ in the resolving and $5 \%$ in the stacking gel. The composition of the gels is depicted in the Table S2. $\dagger$ Twenty $\mu \mathrm{L}$ of each sample were loaded into each well of the gel. The native PAGE was run at r.t. and $80 \mathrm{~V}$ until the dye front reached the resolving gel and then increased up to 140$160 \mathrm{~V}$. After electrophoresis, the gel was washed for $1 \mathrm{~min}$ in $\mathrm{H}_{2} \mathrm{O}$ and exposed for $10 \mathrm{~min}$ to a reusable imaging plate (Fujifilm). Following electronic autoradiography using a radioluminography laser scanner, the gel was stained with PageBlue protein staining solution (Thermo Fisher Scientific) according to the manufacturer's instructions. Quantitative analysis of average band intensities was performed with the Advanced Image Data Analysis (AIDA) program (Raytest).

\section{Serum assay}

Upon delivery, human serum "Off the clot" was split into aliquots $(10 \mathrm{~mL})$ and stored at $-20^{\circ} \mathrm{C}$. For serum experiments, aliquots were thawed on ice and filtered using syringe filters with a pore size of $0.45 \mu \mathrm{m}$. After mixing filtered serum $(220 \mu \mathrm{L})$ with $1 \mathrm{M}$ HEPES/NaOH buffer $\mathrm{pH} 7.4(45 \mu \mathrm{L}),\left[{ }^{64} \mathrm{Cu}\right] \mathrm{Cu}$-labelled 
ligands 1-6 or $\left[{ }^{64} \mathrm{Cu}\right] \mathrm{Cu}-\mathrm{NOTA}-\mathrm{sdAbs}(9 \mathrm{nmol}, 135 \mu \mathrm{L}, \sim 9 \mathrm{MBq})$ were added. Following incubation for $1 \mathrm{~h}$ at $37^{\circ} \mathrm{C}, 2 \times$ Laemmli sample buffer (400 $\mu \mathrm{L}$, Bio-Rad Laboratories, Cat. \#161-0737) was added. Importantly, no reducing agent was added to the Laemmli buffer and the samples were not heated. The mixtures were separated using non-reducing SDS-polyacrylamide gel electrophoresis (SDS-PAGE) with acrylamide concentrations of $5 \%$ in the stacking and $10 \%$ in the resolving gel. For samples containing $\left[{ }^{64} \mathrm{Cu}\right] \mathrm{Cu}-\mathrm{NOTA}-\mathrm{sdAbs}$, an acrylamide concentration of $15 \%$ in the resolving gel was chosen in order to ensure detection of radiolabelled sdAbs. The composition of the gels is depicted in the Table S3. $\dagger$ Two $\mu \mathrm{L}$ of each sample were loaded into each well of the gel. The SDS-PAGE was run at r.t. and $80 \mathrm{~V}$ until the dye front reached the resolving gel and then increased up to 140-160 V. After electrophoresis, the gel was washed for $1 \mathrm{~min}$ in $\mathrm{H}_{2} \mathrm{O}$ and exposed for $10 \mathrm{~min}$ to a reusable imaging plate (Fujifilm). Following electronic autoradiography using a radioluminography laser scanner, the gel was stained with PageBlue protein staining solution (Thermo Fisher Scientific) according to the manufacturer's instructions. As for the SOD challenge, quantitative analyses of average band intensities were performed with the AIDA software.

\section{Kinetic studies}

Time-dependent serum stability assessments were performed after $5 \mathrm{~min}, 1 \mathrm{~h}, 2 \mathrm{~h}$ and $24 \mathrm{~h}$ of incubation at $37^{\circ} \mathrm{C}$ in human serum by choosing $\left[{ }^{64} \mathrm{Cu}\right] \mathrm{Cu}$-diamSar as an example. Radiolabelling of diamSar as well as serum stability assay was performed as described above. Due to the half-life of ${ }^{64} \mathrm{Cu}(12.7 \mathrm{~h})$, the initial activity for radiolabelling was set to $\sim 40 \mathrm{MBq}\left[{ }^{64} \mathrm{Cu}\right]$ $\mathrm{CuCl}_{2}$.

\section{Conclusions}

To date, the described methods represent the first quantitative evaluation to predict the stability of ${ }^{64} \mathrm{Cu}$-containing chelates under physiologically relevant conditions using standard gel electrophoresis techniques. The cost-efficient, rapid and easy to handle procedure of both complementary assays make them a favourable alternative to achieve reliable results which are consistent with in vivo stability, and allow prediction and interpretation of biodistribution data. Herein, we have verified commonly used ${ }^{64} \mathrm{Cu}$ chelates which show an enhanced resistance against transchelation in the presence of excess SOD and albumin. Remarkably, ${ }^{64} \mathrm{Cu}$-labelled diamSar 5 appears to possess the highest kinetic stability of all tested chelators and exhibits a great potential for the development of radiopharmaceuticals based on ${ }^{64} \mathrm{Cu}$. However, as shown for NOTA, conjugation with biomolecules can have a substantial effect on the kinetic stability of the chelate. Both assays presented here, the protein challenge experiment as well as the serum stability assay, are transferable not only to newly designed chelators, but also to those which contain vector molecules such as antibodies, peptides or oligonucleotides. Furthermore, these protocols are not restricted to radiocopper, but may be adopted for other radiometal containing chelates.

\section{Acknowledgements}

We kindly thank the group of Prof Leone Spiccia (Monash University, Melbourne, Australia) for providing the diamSar ligand, as well as Prof Leone Spiccia and Prof Peter Comba (University of Heidelberg, Germany) for their encouraged ideas and critical discussions. Furthermore, we thank Janine Partsch for excellent technical assistance. Financial support by the Helmholtz Virtual Institute NanoTracking (Agreement Number VH-VI-421) is gratefully acknowledged. This study is part of a research initiative "Technologie und Medizin - Multimodale Bildgebung zur Aufklärung des in vivo Verhaltens von polymeren Biomaterialien" of the Helmholtz-Portfoliothema.

\section{Notes and references}

1 C. J. Anderson and R. Ferdani, Cancer Biother. Radiopharm., 2009, 24, 379-393.

2 P. J. Blower, J. S. Lewis and J. Zweit, Nucl. Med. Biol., 1996, 23, 957-980.

3 M. D. Bartholomä, Inorg. Chim. Acta, 2012, 389, 36-51.

4 R. Delgado, V. Felix, L. M. Lima and D. W. Price, Dalton Trans., 2007, 2734-2745.

5 P. S. Donnelly, Dalton Trans., 2011, 40, 999-1010.

6 M. Shokeen and C. J. Anderson, Acc. Chem. Res., 2009, 42, 832-841.

7 S. V. Smith, J. Inorg. Biochem., 2004, 98, 1874-1901.

8 T. J. Wadas, E. H. Wong, G. R. Weisman and C. J. Anderson, Curr. Pharm. Des., 2007, 13, 3-16.

9 T. J. Wadas, E. H. Wong, G. R. Weisman and C. J. Anderson, Chem. Rev., 2010, 110, 2858-2902.

10 M. F. Tweedle, Acc. Chem. Res., 2009, 42, 958-968.

11 M. T. Ma and P. S. Donnelly, Curr. Top. Med. Chem., 2011, 11, 500-520.

12 B. M. Zeglis and J. S. Lewis, Dalton Trans., 2011, 40, 61686195.

13 M. Fani and H. R. Maecke, Eur. J. Nucl. Med. Mol. Imaging, 2012, 39(suppl. 1), S11-S30.

14 A. L. Vavere and R. Rossin, Anticancer Agents Med. Chem., 2012, 12, 462-475.

15 P. Laverman, J. K. Sosabowski, O. C. Boerman and W. J. Oyen, Eur. J. Nucl. Med. Mol. Imaging, 2012, 39(suppl. 1), S78-S92.

16 D. Ma, F. Lu, T. Overstreet, D. E. Milenic and M. W. Brechbiel, Nucl. Med. Biol., 2002, 29, 91-105.

17 V. Maheshwari, J. L. J. Dearling, S. T. Treves and A. B. Packard, Inorg. Chim. Acta, 2012, 393, 318-323.

18 I. Novak-Hofer, R. Waibel, K. Zimmermann, R. Schibli, J. Grunberg, K. A. Chester, A. Murray, B. K. Lo, A. C. Perkins and P. A. Schubiger, Methods Mol. Biol., 2004, 248, 481-494.

19 C. Glaus, R. Rossin, M. J. Welch and G. Bao, Bioconjugate Chem., 2010, 21, 715-722.

20 M. Shokeen, N. M. Fettig and R. Rossin, Q. J. Nucl. Med. Mol. Imaging, 2008, 52, 267-277.

21 G. Gasser, L. Tjioe, B. Graham, M. J. Belousoff, S. Juran, M. Walther, J. U. Künstler, R. Bergmann, H. Stephan and L. Spiccia, Bioconjugate Chem., 2008, 19, 719-730. 
22 S. Juran, M. Walther, H. Stephan, R. Bergmann, J. Steinbach, W. Kraus, F. Emmerling and P. Comba, Bioconjugate Chem., 2009, 20, 347-359.

23 M. Kuhlmann, H. Stephan, J. Steinbach and A. Röhrich, Nucl. Med. Biol., 2010, 37, 681-681.

24 P. Comba, S. Hunoldt, M. Morgen, J. Pietzsch, H. Stephan and H. Wadepohl, Inorg. Chem., 2013, 52, 8131-8143.

25 J. Kotek, P. Lubal, P. Hermann, I. Cisarova, I. Lukes, T. Godula, I. Svobodova, P. Taborsky and J. Havel, Chem. Eur. J., 2003, 9, 233-248.

26 J. A. Barreto, M. Matterna, B. Graham, H. Stephan and L. Spiccia, New J. Chem., 2011, 35, 2705-2712.

27 K. S. Woodin, K. J. Heroux, C. A. Boswell, E. H. Wong, G. R. Weisman, W. J. Niu, S. A. Tomellini, C. J. Anderson, L. N. Zakharov and A. L. Rheingold, Eur. J. Inorg. Chem., 2005, 4829-4833.

28 D. N. Pandya, J. Y. Kim, J. C. Park, H. Lee, P. B. Phapale, W. Kwak, T. H. Choi, G. J. Cheon, Y. R. Yoon and J. Yoo, Chem. Commun., 2010, 46, 3517-3519.

29 D. L. Kukis, H. Diril, D. P. Greiner, S. J. DeNardo, G. L. DeNardo, Q. A. Salako and C. F. Meares, Cancer, 1994, 73, 779-786.

30 P. J. Barnard, S. R. Bayly, J. P. Holland, J. R. Dilworth and P. A. Waghorn, Q. J. Nucl. Med. Mol. Imaging, 2008, 52, 235-244.

31 L. A. Bass, M. Wang, M. J. Welch and C. J. Anderson, Bioconjugate Chem., 2000, 11, 527-532.

32 C. A. Boswell, X. Sun, W. Niu, G. R. Weisman, E. H. Wong, A. L. Rheingold and C. J. Anderson, J. Med. Chem., 2004, 47, 1465-1474.

33 M. S. Cooper, M. T. Ma, K. Sunassee, K. P. Shaw, J. D. Williams, R. L. Paul, P. S. Donnelly and P. J. Blower, Bioconjugate Chem., 2012, 23, 1029-1039.

34 B. E. Kim, T. Nevitt and D. J. Thiele, Nat. Chem. Biol., 2008, 4, 176-185.

35 T. Nevitt, H. Ohrvik and D. J. Thiele, Biochim. Biophys. Acta, 2012, 1823, 1580-1593.

36 S. Lutsenko, Curr. Opin. Chem. Biol., 2010, 14, 211-217.

37 J. L. Burkhead, K. A. Reynolds, S. E. Abdel-Ghany, C. M. Cohu and M. Pilon, New Phytol., 2009, 182, 799-816.

38 D. Osman and J. S. Cavet, Adv. Appl. Microbiol., 2008, 65, 217247.

39 M. L. Turski and D. J. Thiele, J. Biol. Chem., 2009, 284, 717721.

40 M. C. Linder, Mutat. Res., 2012, 733, 83-91.

41 K. Jomova and M. Valko, Toxicology, 2011, 283, 65-87.

42 M. Moriya, Y.-H. Ho, A. Grana, L. Nguyen, A. Alvarez, R. Jamil, M. L. Ackland, A. Michalczyk, P. Hamer, D. Ramos, S. Kim, J. F. B. Mercer and M. C. Linder, Am. J. Physiol. Cell. Physiol., 2008, 295, C708-C721.

43 M. C. Linder, N. A. Lomeli, S. Donley, F. Mehrbod, P. Cerveza, S. Cotton and L. Wotten, Adv. Exp. Med. Biol., 1999, 448, 1-16.

44 S. J. Lau and B. Sarkar, J. Biol. Chem., 1971, 246, 59385943.

45 J. Masuoka, J. Hegenauer, B. R. Van Dyke and P. Saltman, J. Biol. Chem., 1993, 268, 21533-21537.
46 R. A. Bradshaw and T. Peters, Jr, J. Biol. Chem., 1969, 244, 5582-5589.

47 D. T. Gordon, A. S. Leinart and R. J. Cousins, Am. J. Physiol., 1987, 252, E327-E333.

48 R. S. Ohgami, D. R. Campagna, A. McDonald and M. D. Fleming, Blood, 2006, 108, 1388-1394.

49 F. Arnesano, L. Banci, I. Bertini and S. Ciofi-Baffoni, Eur. J. Inorg. Chem., 2004, 8, 1583-1593.

50 T. D. Rae, P. J. Schmidt, R. A. Pufahl, V. C. Culotta and T. V. O'Halloran, Science, 1999, 284, 805-808.

51 L. Banci, I. Bertini, F. Cantini and S. Ciofi-Baffoni, Cell. Mol. Life Sci., 2010, 67, 2563-2589.

52 T. V. O'Halloran and V. C. Culotta, J. Biol. Chem., 2000, 275, 25057-25060.

53 P. Palumaa, FEBS Lett., 2013, 587, 1902-1910.

54 V. C. Culotta, M. Yang and T. V. O'Halloran, Biochim. Biophys. Acta, 2006, 1763, 747-758.

55 I. Fridovich, Annu. Rev. Biochem., 1995, 64, 97-112.

56 L. O. Gainkam, L. Huang, V. Caveliers, M. Keyaerts, S. Hernot, I. Vaneycken, C. Vanhove, H. Revets, P. De Baetselier and T. Lahoutte, J. Nucl. Med., 2008, 49, 788795.

57 A. Gschwind, O. M. Fischer and A. Ullrich, Nat. Rev. Cancer, 2004, 4, 361-370.

58 J. Havlickova, H. Medova, T. Vitha, J. Kotek, I. Cisarova and P. Hermann, Dalton Trans., 2008, 5378-5386.

59 K. J. Heroux, K. S. Woodin, D. J. Tranchemontagne, P. C. Widger, E. Southwick, E. H. Wong, G. R. Weisman, S. A. Tomellini, T. J. Wadas, C. J. Anderson, S. Kassel, J. A. Golen and A. L. Rheingold, Dalton Trans., 2007, 21502162.

60 R. Ferdani, D. J. Stigers, A. L. Fiamengo, L. H. Wei, B. T. Y. Li, J. A. Golen, A. L. Rheingold, G. R. Weisman, E. H. Wong and C. J. Anderson, Dalton Trans., 2012, 41, 1938-1950.

61 R. Rakhit and A. Chakrabartty, Biochim. Biophys. Acta, 2006, 1762, 1025-1037.

62 S. Chevreux, I. Llorens, P. L. Solari, S. Roudeau, G. Deves, A. Carmona, D. Testemale, J. L. Hazemann and R. Ortega, Electrophoresis, 2012, 33, 1276-1281.

63 M. Sato and J. D. Gitlin, J. Biol. Chem., 1991, 266, 5128-5134. 64 J. M. Lafky, J. A. Wilken, A. T. Baron and N. J. Maihle, Biochim. Biophys. Acta, 2008, 1785, 232-265.

65 R. J. Motekaitis, B. E. Rogers, D. E. Reichert, A. E. Martell and M. J. Welch, Inorg. Chem., 1996, 35, 3821-3827.

66 R. Delgado and J. J. da Silva, Talanta, 1982, 29, 815-822.

67 B. E. Rogers, C. J. Anderson, J. M. Connett, L. W. Guo, W. B. Edwards, E. L. Sherman, K. R. Zinn and M. J. Welch, Bioconjugate Chem., 1996, 7, 511-522.

68 G. A. Bottomley, I. J. Clark, I. I. Creaser, L. M. Engelhardt, R. J. Geue, K. S. Hagen, J. M. Harrowfield, G. A. Lawrance, P. A. Lay, A. M. Sargeson, A. J. See, B. W. Skelton, A. H. White and F. R. Wilner, Aust. J. Chem., 1994, 47, 143-179.

69 S. Thieme, M. Walther, H. J. Pietzsch, J. Henniger, S. Preusche, P. Mading and J. Steinbach, Appl. Radiat. Isot., 2012, 70, 602-608.

70 K. Zarschler, S. Witecy, F. Kapplusch, C. Foerster and H. Stephan, Microb. Cell. Fact., 2013, 12, 97. 